Article

\title{
Mealworms for Food: A Water Footprint Perspective
}

\author{
Pier Paolo Miglietta ${ }^{\dagger}$, Federica De Leo ${ }^{\dagger} * *$, Marcello Ruberti ${ }^{\dagger}$ and Stefania Massari $^{\dagger}$ \\ Department of Management, Economics, Mathematics and Statistics, University of Salento, \\ via per Monteroni, Lecce 73100, Italy; E-Mails: pierpaolo.miglietta@unisalento.it (P.P.M.); \\ marcello.ruberti@unisalento.it (M.R.); stefania.massari@unisalento.it (S.M.)
}

$\dagger$ These authors contributed equally to this work.

* Author to whom correspondence should be addressed; E-Mail: federica.deleo@unisalento.it; Tel.: +39-0832-298-628; Fax: +39-0832-298-752.

Academic Editor: Stephan Pfister

Received: 6 August 2015 / Accepted: 3 November 2015 / Published: 6 November 2015

\begin{abstract}
In this paper, we have explored the possibility of substituting traditional meat products with an alternative source of protein (insects) in order to reduce human pressure on water. Insects, in fact, could represent a good alternative source of quality proteins and nutrients and they are already a very popular component of the diet of one third of the world's population in approximately $80 \%$ of countries. In the study, we have taken into account only two species of edible insects (Tenebrio molitor and Zophobas morio mealworms), because they are already commercially produced even in Western countries, and for this reason it is possible to find specific data in literature about their diets. We have used the water footprint (WF) as a reliable indicator to calculate the volume of water required for production and to compare different products. The final aim of the work is, in fact, to evaluate the WF of the production of edible insects with a focus on water consumption associated with protein content, in order to make a comparison with other animal protein sources. We have demonstrated that, from a freshwater resource perspective, it is more efficient to obtain protein through mealworms rather than other traditional farmed animals.
\end{abstract}

Keywords: livestock; insects; mealworms; food; freshwater; water footprint 


\section{Introduction}

As a fundamental resource for life, water has represented a key factor for human development and a central issue for the international community for many years. Nowadays, "scarcity" is one of the adjectives most associated with the word "water" [1]. Many areas of the world have reached critical levels and can be considered water scarce [2].

The Intergovernmental Panel on Climate Change (IPCC) Fourth Assessment Report identifies climate change, future population growth, and economic and land-use change as the most inherent reasons for the increase in water stress [3]. The perspective in the world population growth rate [4] states that the higher food demand will imply a direct effect on agricultural water usage in the future.

It is estimated that agriculture is currently responsible for $70 \%$ of global water withdrawals [5], and nearly a third of that is attributed to livestock production and, in turn, a third of this is related to beef cattle [6]. Today, livestock production inflicts great ecological damage, such as GHG (greenhouse gas) emissions, acidification, nitrification and erosion of soil, eutrophication, biodiversity loss, and global freshwater stress [7-9]. In addition, the FAO (Food and Agriculture Organization of the United Nations) has foreseen that global meat production and consumption will double by 2050, compared to 2000 [7]. This increase in consumption will have a further negative impact on the amount of freshwater available in the coming decades [10].

According to the FAO, the world population is steadily increasing and will reach the threshold of 9 billion people by 2050. This will involve, first of all, a greater need for food, especially for animal protein sources (from cattle, pork, poultry, and fish), and greater consequences on freshwater resources, environment, and sustainability $[11,12]$.

In this context, there is the need, for example, to rethink our current food patterns and habits for the future, in order to reduce the pressure on freshwater resources. The need to quantify and take into account the water consumption needed for the production of a particular good comes from the fact that, the reserves of fresh water on our planet are evidently very scarce and are critical to the survival of the species, and to ensure human development in the future generations.

Among the several available indicators able to take into account the water consumption of production cycles, the WF is relatively easy to calculate and communicate, and it allows us to compare different products and services on the basis of the volume of water required to produce them [13].

The aim of this work is to assess the WF of the production of edible insects with a focus also on the water consumption linked to their protein content and, finally, to provide a comparison with other animal protein sources.

Entomophagy, in fact, could represent a good alternative source of quality proteins and nutrients - such as unsaturated and essential fatty acids (especially omega 3 and 6), vitamins (the same high content of B12 of fish), fibers, and minerals (15\% more iron than spinach) — even for the inhabitants of developed countries [14-16].

In fact, for several centuries in many regions of the world, insects have been a very popular component of the diet, both as an effective source of essential nutrients and as a functional food [17,18]. Nowadays, there are about 2000 species of insects regularly eaten in the world by about two billion people (over 3000 ethnic groups), i.e., one third of the world population, in approximately $80 \%$ of countries $[19,20]$. 
In this paper, we have determined the water footprint of two types of mealworms (Coleoptera: Tenebrionidae) that are of great interest for human consumption: the yellow mealworm (Tenebrio molitor L.) and the super worm (Zophobas morio L.). Both mealworms are promising and valid alternative sources of nutrients for humans [11] and both can be reared very well on organic side streams [20].

\section{Materials and Methods}

For the aim of this paper, we have considered two farmed mealworm species, which have easy rearing methods and have been commercially produced as larvae on an industrial scale for several years, representing an important source of food [21], and we have then estimated the total feed amounts and the total water footprints.

A cradle-to-farm gate approach was chosen, which means that the water impact was assessed up to the moment that the fresh product leaves the farm gate.

Our paper is based on an Oonincx and de Boer study [22], which considers a commercial mealworm producer (van de Ven Insectenkwekerij, Deurne, The Netherlands), who produces the two mealworm species (T. molitor L. and Z. morio L.) in the same way and in equal proportions ( $\mathrm{kg} / \mathrm{year}$ ). The production system considered in this paper, including the diet, is identical for both mealworm species. The diet consisted of a mixed grain substrate (i.e., wheat bran, oats, soy, rye and corn, supplemented with beer yeast) with pieces of fresh carrots on top [23]. The quantities of all inputs and the output of the production system (Table 1) were extracted from Oonincx and de Boer [22].

Table 1. Resource use per year of the mealworm farm considered in the study.

\begin{tabular}{cc}
\hline Resource Input & Turnover/Year \\
\hline Carrots $(\mathrm{kg})$ & 260,000 \\
Mixed grains $(\mathrm{kg})$ & 182,000 \\
Direct real water $\left(\mathrm{m}^{3}\right)$ & 211 \\
Mealworms output $(\mathrm{kg})$ & 83,200 \\
\hline Note: Based on Oonincx and de Boer data [22].
\end{tabular}

We followed the water footprint definitions and methodology as set out in Aldaya et al. [24]. The WF represents, in particular, the total amount of freshwater required to produce or consume, directly or indirectly, goods and services including production, harvesting, processing, packaging, and distribution. The WF consists of three components: blue water, which is irrigation water; green water, which is the rainwater either used by plants or evapotranspirated; grey water, namely the amount of water required to dilute pollutants. Of these three components, certainly the one that is the most responsible for environmental problems (such as the consumption of water resources, loss of agricultural land, and salinization) is blue water [24].

The water footprint of a live animal generally consists of different components: the indirect water footprint of the feed, the direct water footprint related to the drinking water, and service water consumed during the farming stage $[25,26]$. The water footprint of an animal is expressed as:

$$
\mathrm{WF}_{\text {animal }}=\mathrm{WF}_{\text {feed }}+\mathrm{WF}_{\text {drink }}+\mathrm{WF}_{\text {serv }}
$$


where $\mathrm{WF}_{\text {feed, }}, \mathrm{WF}_{\text {drink }}$ and $\mathrm{WF}_{\text {serv }}$ represent, respectively, the water footprint of an animal related to feed, drinking water, and service-water consumption, which, in turn, refers to the water used to clean the farmyard and carry out other services necessary to support the production process and to maintain the environment. The water footprint of an animal and its three components can be expressed in terms of $\mathrm{m}^{3}$ /year/animal, or, when divided by the lifetime of the animal, in terms of $\mathrm{m}^{3} /$ animal.

The water footprint of an animal related to the feed consumed consists of two parts: the water footprint of the various feed ingredients and the water that is used to mix the feed [6]:

$$
\mathrm{WF}_{\mathrm{Feed}}=\frac{\left(\text { Feed } \times \mathrm{WF}^{*}{ }_{\text {prod }}\right)+\mathrm{WF}_{\text {mixing }}}{\text { Pop }^{*}}
$$

Feed represents the annual amount of feed ingredients consumed by the animal category considered in the production system ( $\mathrm{t} /$ year). $\mathrm{WF}^{*}$ prod is the water footprint of feed ingredients $\left(\mathrm{m}^{3} / \mathrm{t}\right), \mathrm{WF}$ mixing is the volume of water consumed for mixing the feed $\left(\mathrm{m}^{3} /\right.$ year/animal), and Pop* is the number of animals produced per year.

Even if the water footprints of the feed may vary in relation to the production origin, the different productive systems, and the different diets, since it does not imply significant variation for the aim of this study, which represents a first assessment, we have considered global average values as already done in previous scientific literature [6] in order to simplify the comparison of our results.

The water footprints of the different crops, roughages, and crop by-products (WF* ${ }^{*}$ prod, $\mathrm{m}^{3} / \mathrm{t}$ ) that are eaten by the insect categories considered in this study were extracted from Mekonnen and Hoekstra [27,28], considering their average global value.

Since the actual mixed grain feed is a commercial secret and the single ingredient percentages are not disclosed by Oonincx and de Boer in their article due to agreements between the authors and the producer [22], we assumed that the mixed grain feed consists of an equal quantity of each component, but we also conducted a sensitivity analysis in order to take into account the water footprint variability related to the different concentrations of the ingredients.

Reasonably, due to the fact that the mixed grain feed is composed of five different ingredients, we assume that the concentration of each of them in the mix is equiprobable and cannot be less than $5 \%$ of the total.

Based on this analysis, we observed that with a probability of $95 \%$, the mixed grain water footprint value ranges between its average expected value $\pm 188 \mathrm{~m}^{3} / \mathrm{t}$.

Subsequently, we multiplied the global average water footprint of a ton of concentrates and a ton of carrots by the quantity of mixed grain feed and carrots required for the annual production farming. In this way, we obtained the annual virtual water (i.e., the use of indirect water to support the feeding of mealworms) expressed in terms of $\mathrm{m}^{3}$.

We then summed this value of virtual water to the direct use of real water needed by the insects for growth and for cleaning the farmyard and carrying out other services necessary to support the production process and to maintain the environment.

From this computation, we obtained the quantity of (direct and indirect) water consumed to support the annual production of mealworms. Dividing this value by the annual output of the farming process expressed in ton of mealworms per year, we obtained the water footprint of a ton of mealworms in terms of $\mathrm{m}^{3} / \mathrm{t}$. 
In order to obtain the water footprint of an individual animal, in this case a mealworm we multiplied the value of the water footprint of a ton of mealworms by the average mass of a single mealworm at the end of its life cycle. In this way we obtained the average value of the water footprint of each mealworm at the end of its useful life expressed in $\mathrm{m}^{3} / \mathrm{t}$. Furthermore, dividing this value by the average lifespan of farmed mealworms expressed in years, we extracted the average annual water footprint of a mealworm.

To compute the value of water footprint per unit of edible protein, firstly we multiplied the quantity of output expressed in $\mathrm{kg}$ of fresh mealworms produced with the average reported dry matter content (T. molitor 38\%; Z. morio $43 \%$ ) and the average percentage of reported crude protein in the dry matter (T. molitor 53\%; Z. morio 45\%) [29-31].

Crude protein in the dry matter is estimated as total nitrogen concentration multiplied by a coefficient assumed to represent the density of nitrogen in an average protein (6.25). In the specific case of insects, nitrogen occurs both in proteins and also in the exoskeleton, bound in chitin. Chitin-bound nitrogen has already been measured in scientific literature for T. molitor and Z. morio, corresponding to the value of $5 \%-6 \%$ of the total nitrogen [29,32]. We therefore estimated the total nutritional content of the mealworms in terms of protein detracting the chitin-bound nitrogen.

Subsequently, we multiplied the obtained value of available dietary proteins by the edible portion, which we consider to be $100 \%$ for mealworms since humans consume the whole animal. The protein content and edible portion of common production animals vary depending on the breed, country of production, and other factors. In this study we used the data reported by de Vries and de Boer [33] and Smil [34].

The results obtained from the analysis were compared with the same values reported in literature by Mekonnen and Hoekstra [6] for other types of animals raised for human food consumption, in order to extract the results useful in the discussion of the hypotheses of this paper.

\section{Results}

The WF of a specific farmed insect is determined by the water consumption and pollution in each farming process step within the supply chain of the final product. From the perspective of water consumption and pollution, the most important contributors are: water used for growing the feed, water necessary for the animals' growth, and water used on the farm for cleaning. Actually, in the supply chain of an animal farming system there are more processes than these, but all these processes imply a very small percentage of the total WF of the final animal product [6].

Among the three processes studied here-feed production, growing, and farm cleaning - the first one represents the largest factor. The WF of farmed animal products depends on three main factors: (i) how much the animals eat; (ii) what the animals eat, i.e., the feed composition; and (iii) the feed origin that determines the WF of the livestock feed.

The WF at a specific location is determined by local climatic conditions, such as rainfall, moisture, and temperature, in combination with soil conditions and agricultural practice. In general, high yield levels go along with relatively small WFs and the inverse is also true. The WF of the total feed package depends on the feed composition and the origin of the various feed ingredients. 
The water use for mealworm production in the rest of the chain is a minor part of the total WF of animal products. Figure 1 schematically shows the factors determining the WF of mealworms.

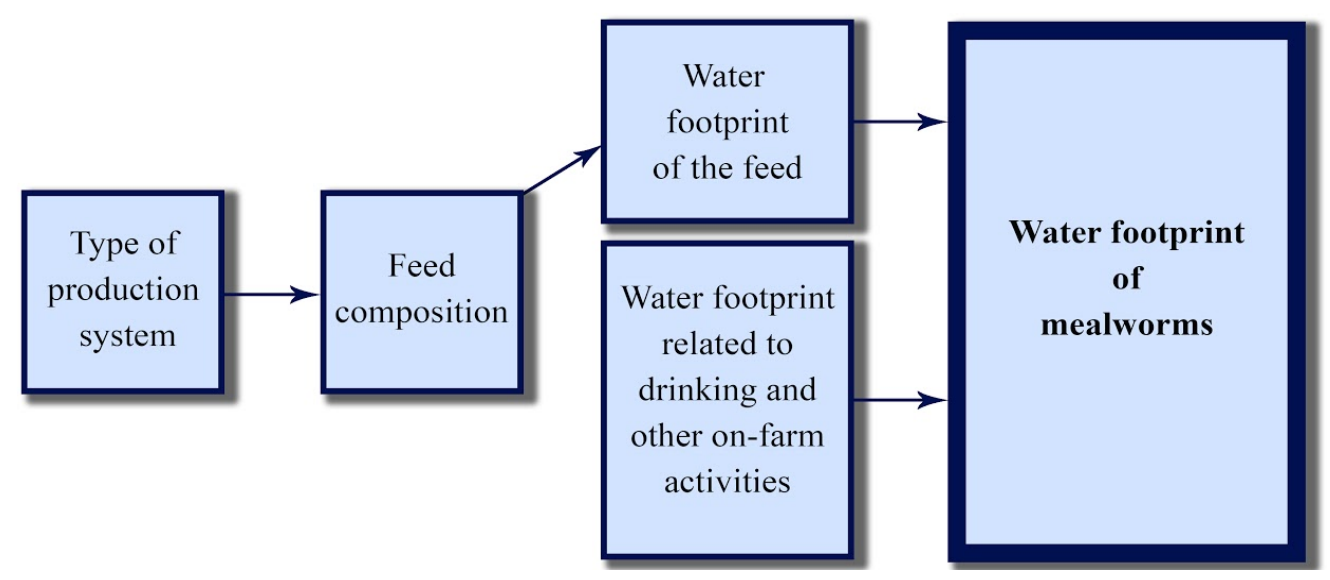

Figure 1. Factors determining the water footprint of farmed mealworms.

An important underlying factor for animal meat is the type of production system, since the type of system influences the feed conversion efficiency, the feed composition, and the origin of the feed.

Feed conversion efficiencies depend on the type of production system. In general, feed conversion efficiency improves from grazing to mixed systems to industrial systems.

The second main factor influencing the WF of mealworms is the WF of the animal feed. This depends on the composition and the origin of the feed.

The farming system analyzed in this study is an industrial production with a relatively large fraction of concentrates in the animal feed [35]. The WF of the feed considered in the analysis is assumed to be the global average, not taking into account the origin of the feed.

Since the WF of mealworms is dominated by the WF of the animal feed, the composition of the feed is an important factor. Table 2 gives the main components contained in feed concentrates and roughages, and shows that there are large differences between the WFs $\left(\mathrm{m}^{3}\right.$ of water per ton of feed) of mixed grain feed and carrots. Mixed grain feed has a relatively large WF, while carrots have a relatively small WF. On average, the WF of mixed grain feed is almost nine times larger than the WF of carrots. While carrots have a WF of around $195 \mathrm{~m}^{3} / \mathrm{t}$ (global average), the value for the mix grain feed is about $1704.6 \mathrm{~m}^{3} / \mathrm{t}$ (with a variation of $\pm 188 \mathrm{~m}^{3} / \mathrm{t}$ based on the differences in terms of ingredient concentration observed through the sensitivity analysis). As the incidence of green WF for the mixed grains and the carrots are respectively $84 \%$ and $54.36 \%$ of the total WF, it implies that carrots need much more irrigation than mixed grain feed. Even if the green, blue, and grey WF components of the mixed grains are respectively 13.5, 5 and 2.6 times larger than those of carrots, in relative terms the percentage of the grey component of the total WF for carrots is $31.28 \%$, this meaning a relevant incidence of pollutants in the cultivation of carrots.

Considering an annual consumption of food for the mealworms equal to $182 \mathrm{t}$ of mixed grains and $260 \mathrm{t}$ of carrots [22], we obtained the two values of consumption of virtual water amounting to $310,237.2 \mathrm{~m}^{3}$ for mixed grains and $50,700 \mathrm{~m}^{3}$ for carrots. Summing up these values we calculated the value of virtual water consumed to sustain the complete diet of insects, as shown in Table 3. 
Table 2. Global average water footprints of the different crops, roughages, and crop by-products included in the mealworm farming system.

\begin{tabular}{ccccc}
\hline \multirow{2}{*}{ Crops, Roughages and Crop by-Products } & \multicolumn{4}{c}{ Global Average Water Footprint in $\mathbf{~ m}^{\mathbf{3}} / \mathbf{t}$} \\
\cline { 2 - 5 } & Green & Blue & Grey & Total WF \\
\hline Maize (corn) & 947 & 81 & 194 & 1222 \\
Rye & 1419 & 25 & 99 & 1543 \\
Oats & 1479 & 181 & 128 & 1788 \\
Soybeans & 2037 & 70 & 37 & 2144 \\
Wheat bran & 1277 & 342 & 207 & 1826 \\
Mixed grain & 1431.8 & 139.8 & 133 & $\mathbf{1 7 0 4 . 6}$ \\
\% of WF component for the mixed grain feed & 84 & 8.2 & 7.8 & 100 \\
Carrots and turnips & 106 & 28 & 51 & $\mathbf{1 9 5}$ \\
\% of WF component for the carrots & 54.36 & 14.36 & 31.28 & 100 \\
\hline
\end{tabular}

Note: Based on Mekonnen and Hoekstra data [27].

Table 3. Annual virtual water consumption of the farmed insect diet.

\begin{tabular}{cccc}
\hline Diet components & Total WF in $\mathbf{~ m}^{\mathbf{3}} / \mathbf{t}$ & $\begin{array}{c}\text { Farming Consumption } \\
\text { in Ton of Product }\end{array}$ & $\begin{array}{c}\text { Virtual Water } \\
\text { Consumption in } \mathbf{~ m}^{\mathbf{3}}\end{array}$ \\
\hline Mixed grain feed & 1704.6 & 182 & $310,237.2$ \\
Carrots and turnips & 195 & 260 & 50,700 \\
\hline Complete diet & - & - & $\mathbf{3 6 0 , 9 3 7 . 2}$ \\
\hline
\end{tabular}

The value of virtual water for the overall diet planned for breeding mealworms, amounting to $360,937.2 \mathrm{~m}^{3}$, has been added to the direct use of real water equal to $211 \mathrm{~m}^{3}$ as indicated in Table 1 , for mealworm life $\left(\mathrm{WF}_{\text {drink }}\right)$ and farm services $\left(\mathrm{WF}_{\text {serv }}\right)$, in order to obtain a total value of real and virtual water consumption amounting to $361,148.2 \mathrm{~m}^{3}$. This result, divided by the output of livestock production amounted to $83.2 \mathrm{t}$ of mealworms as extracted from Oonincx and de Boer [22] and shown in Table 1, gives rise to the water footprint for the production of mealworms, which is equal to $4341 \mathrm{~m}^{3} / \mathrm{t}$, as indicated in Table 4.

Table 4. Virtual water consumption of the farmed insect diet.

\begin{tabular}{cccc}
\hline Type of production & $\begin{array}{c}\text { Water Consumption in } \\
\mathbf{m}^{\mathbf{3}} \text { (Virtual + Real) }\end{array}$ & $\begin{array}{c}\text { Mealworms Output } \\
\text { per Year in Ton }\end{array}$ & $\begin{array}{c}\text { Water Footprint of a Ton of } \\
\text { Farmed Mealworms in } \mathbf{~ m}^{\mathbf{3}} / \mathbf{t o n}\end{array}$ \\
\hline $\begin{array}{c}\text { Production of } \\
\text { mealworms for humans }\end{array}$ & $361,148.2$ & 83.2 & 4341 \\
\hline
\end{tabular}

If we compare the average total annual water footprint per animal ( $\left.\mathrm{WF}_{\text {feed }}+\mathrm{WF}_{\text {drink }}+\mathrm{WF}_{\text {serv }}\right)$ of different animal categories (Table 5), we find that beef cattle have the largest (631 $\mathrm{m}^{3} /$ year/animal) among farm animal production, followed by pigs ( $521 \mathrm{~m}^{3} /$ year/animal), broiler chickens ( $26 \mathrm{~m}^{3} /$ year/animal), and mealworms, which obviously have the lowest water impact $\left(0.003 \mathrm{~m}^{3} /\right.$ year/animal $)$ due to their very low weight. 
Table 5. Average annual water footprint of a single animal per animal category.

\begin{tabular}{|c|c|c|c|c|c|}
\hline Animal Category & $\begin{array}{l}\text { Water Footprint of } \\
\text { Live Animal at the } \\
\text { End of Life }\left(\mathrm{m}^{3} / \mathrm{t}\right)\end{array}$ & $\begin{array}{l}\text { Average Animal } \\
\text { Weight at the End } \\
\text { of Life Time (kg) }\end{array}$ & $\begin{array}{c}\text { Average Water Footprint } \\
\text { of One Animal at the End } \\
\text { of Life Time }\left(\mathrm{m}^{3} / \mathrm{t}\right)\end{array}$ & $\begin{array}{l}\text { Average Life } \\
\text { Time (year) }\end{array}$ & $\begin{array}{c}\text { Average Annual Water } \\
\text { Footprint of One Animal } \\
\quad\left(\mathrm{m}^{3} / \text { year/animal }\right)\end{array}$ \\
\hline Mealworms & 4341 & $1.81 \times 10^{-4} *$ & $7.81 \times 10^{-4}$ & $0.25 * *$ & 0.003 \\
\hline Pigs ${ }^{a}$ & 3831 & 102 & 390.76 & 0.75 & 521.016 \\
\hline Broiler Chickens ${ }^{\text {a }}$ & 3364 & 1.9 & 6.39 & 0.25 & 25.566 \\
\hline Beef cattle ${ }^{a}$ & 7477 & 253 & 1891.68 & 3.00 & 630.560 \\
\hline
\end{tabular}

Notes: ${ }^{a}$ Based on Mekonnen and Hoekstra data [6]. * Based on Aguilar-Miranda et al. data [36], Ghaly and Alkoiak data [37], Siemianowska et al. data [38]. ** Calculated as the average time in which Tenebrio molitor and Zophobas morio reach adulthood based on Oonincx and de Boer data [22].

Even if the WF per ton of live animals for mealworms seems to be higher than other animals, it is important to underline that the edible portion for mealworms is considered to be $100 \%$ since humans consume the whole animal, contrary to the other food products, as revealed by the difference in water footprint values between live animals (Table 5) and their related edible portions (Table 6). This leads to the WF values expressed per edible ton reported in Table 6, in which it is evident that the values for mealworms are comparable to chicken meat and lower than all the other animal meat categories.

Table 6. The water footprint of food products from animal origin in terms of protein value.

\begin{tabular}{|c|c|c|c|}
\hline Food Item & $\begin{array}{c}\text { Water Footprint per } \\
\text { Edible Ton }\left(\mathbf{m}^{3} / \mathbf{t}\right)\end{array}$ & $\begin{array}{c}\text { Nutritional Content in Terms } \\
\text { of Protein (g/edible kg) }\end{array}$ & $\begin{array}{c}\text { Water Footprint per Unit of } \\
\text { Nutritional Value (L/g Protein) }\end{array}$ \\
\hline Mealworms & 4341 & $186 *$ & 23 \\
\hline Pig meat ${ }^{\mathrm{a}}$ & 5988 & 105 & 57 \\
\hline Chicken meat ${ }^{a}$ & 4325 & 127 & 34 \\
\hline Beef $^{a}$ & 15,415 & 138 & 112 \\
\hline
\end{tabular}

If we look at the water requirements from a different perspective, in terms of protein, we find that the water footprint per gram of protein for beef, pig, and chicken meat is larger than for mealworms, as shown in Table 6. For beef, the water footprint per gram of protein is five times larger than of mealworms, while the least water-impacting food item, excluding mealworms (23 liters per gram of protein), is represented by chicken meat. This result depends on the high conversion efficiency of mealworms in transforming food into protein, compared to other animals, as well as on their high output turnover due to their high fecundity.

\section{Discussion and Conclusions}

In consideration of the global need for changing food consumption patterns due to the growing concerns about environmental pollution and scarcity of natural resources, and in particular soil and water, we have explored the possibility of substituting traditional meat products with insects as an alternative source of protein, in order to reduce the human pressure on water. We decided to consider the water footprint as a reliable indicator usable for comparisons. In the present study we have taken 
into account only two species of edible insects (T. molitor and Z. morio mealworms) because they are also commercially produced even in Western countries, and for this reason it is possible to find specific data in literature about their diets. The results reported in this paper come from the analysis made on a single farm, so additional research using data from different mealworm farms and rearing systems should be carried out. Our results represent, in any case, a very interesting finding to be taken into account for further discussion.

In general, the main environmental impact of animal protein production is linked to the feed quality and the type of production system [39]. Livestock farming systems can be categorized into three types: grazing, mixed, and industrial systems [40]. Going from one system to the other, the consumption of feed concentrates increases, leading to growing pressure on the natural environment and water resources, due to crop cultivation and feed mixing. Feed concentrates have, in fact, larger WFs than roughages, due to the fact that intensive crops need more irrigation and use of fertilizers; this causes an increase in particular of the grey and blue WF components [35]. The current global trends in meat consumption require more and more industrial farming systems in order to satisfy the demand, but this generally goes in the opposite direction of sustainability. On the other hand, it has been observed that only considering water impact, the high productivity of industrial systems in which the conversion efficiency of feed inputs into meat outputs is very high may offset the negative effects of high concentrate consumption. In this case, the total WF per unit of animal product may be lower [6].

The interest in insects comes from their very high efficiency in transforming phytomass into protein-rich animal biomass, their high fecundity, their very fast growth rates, and also their ability to absorb all the water they need from just their food [37,38,41]. It has also been reported that mealworms do not need any additional drinking water if they are farmed in appropriate humidity conditions and provided with carrots and the appropriate ratio of bran/grains [42]. All these characteristics can lead to an advantage in environmental terms over other animal categories, even when insects are farmed in industrial systems, as currently required by the market.

Considering the water issue, the WF of reared insects (mealworms in our case) is dominated by the WF of the animal feed as we have reported in the paper, so the composition of the feed is an important factor to be taken into account in order to increase the sustainability of meat production. The biggest contributing factor to the total WF related to feed is the mixed grains used in the diet of mealworms (see Table 1), but we emphasized that the carrots added to the mixed grains to provide the necessary moisture have a relative high grey WF component (see Table 2).

If we take into consideration the results of the sensitivity analysis related to the unknown recipe of the mixed grain feed, the variability interval around the average value of the water footprint of farmed mealworms would be $\pm 411 \mathrm{~m}^{3} / \mathrm{t}$. Even considering the minimum and maximum of this interval we obtain values of the water footprint of farmed mealworms respectively equal to $3930 \mathrm{~m}^{3} / \mathrm{t}$ and $4752 \mathrm{~m}^{3} / \mathrm{t}$, which are not in contrast with our results based on the assumed average value of the mixed grain.

In addition, other authors have found that the feed conversion rate of mealworms is dependent on the external temperature during the farming and on the humidity of the substrate, as well as on the diet composition. The use of temperature-controlled rearing containers is then necessary to guarantee optimal results, which in turn translates into a lower WF value [43]. It has also been observed that the consumption of carrots increases when their diet is based on low protein and high starch feeds [44]. These findings give important input for further research aimed at looking for the best combination of 
feed that could reduce the WF of this meat product, in particular the blue and the grey components, as a sustainable meat production means their reduction. Another relevant aspect to be further investigated is the possibility of using organic by-products to integrate the mealworm diet, which would result in two positive effects: reducing the amount of grains and giving value to waste.

In the present study we calculated and compared the WF of live animals and of edible tons, for different categories of traditional meat sources and mealworms. One relevant characteristic of mealworms is that the edible portion corresponds to $100 \%$ of the weight of the live animal, while in pigs, beef, and chickens the edible portion is much less than their live weight, so this contributes to further reducing the WF value of mealworm edible products (see Tables 5 and 6).

Even if the WF for each animal category may vary in different regions, in different productive systems, and with different diets, considering global average values for industrial systems we have demonstrated that from a freshwater resource perspective, it is more efficient to obtain protein through mealworms rather than other traditional farmed animals (see Table 6). This is due to the fact that mealworms have very high feed conversion rates and in addition they have a very high content of protein. The WF of mealworms expressed in terms of liters/g protein results is 23 , compared to that of chicken which is 34 and that of beef which is 112, as shown in Table 6.

One additional property to be taken into consideration when we think of substituting traditional protein sources with insects, is that mealworm proteins are also of good quality in terms of nutritional value, as they contain all the 20 essential amino acids (beef, for example, compared to mealworms has a higher content of only three of these) [11].

In conclusion, we can say that integrating diets with insects and, in particular, with mealworms can contribute to a more sustainable way of feeding the growing human population [45]. The debate on sustainable food is definitely much broader than just water consumption and pollution, but water is a very important resource for life and we have to commit ourselves to saving it as much as we can, even by changing our food habits and meat consumption patterns.

Further research could be addressed to assessing the water footprint of mealworm production with a regional approach to test the productive specialization of different areas around the world, from a water stress reduction perspective.

\section{Acknowledgments}

The authors would like to thank Massimo Frittelli for the significant support given in the sensitivity analysis and Traci Michelle Ricciardo for the extensive English revisions. We also thank two anonymous reviewers for their constructive comments that helped us improve an earlier version of the manuscript.

\section{Author Contributions}

The following authors contributed in full to this work. Marcello Ruberti analyzed the sources and the literature. Federica de Leo contributed to the research design and the data collection. Pier Paolo Miglietta submitted the model and Stefania Massari supervised the research project and carried out a detailed revision. All the authors wrote the body of the paper, read and approved the final manuscript. 


\section{Conflicts of Interest}

The authors declare no conflict of interest.

\section{References}

1. Mancosu, N.; Snyder, R.L.; Kyriakakis, G.; Spano, D. Water scarcity and future challenges for food production. Water 2015, 7, 975-992.

2. Alcamo, J.; Döll, P.; Kaspar, F.; Siebert, S. Global Change and Global Scenarios of Water Use and Availability: An Application of WaterGAP 1.0; University of Kassel Press: Kassel, Germany, 1997.

3. Bates, B.C.; Kundzewicz, Z.W.; Wu, S.; Palutikof, J.P. Climate Change and Water; IPCC Secretariat: Geneva, Switzerland, 2008.

4. United Nations Department of Economic and Social Affairs, Population Division (UNPD). World Population Prospects: The 2012 Revision, Volume II, Demographic Profiles (ST/ESA/SER.A/345); United Nations: New York, NY, USA, 2013.

5. Ridoutt, B.G.; Sanguansri, P.; Freer, M.; Harper, G.S. Water footprint of livestock: Comparison of six geographically defined beef production systems. Int. J. Life Cycle Assess. 2012, 17, 165-175.

6. Mekonnen, M.M.; Hoekstra, A.Y. A global assessment of the water footprint of farm animal products. Ecosystems 2012, 15, 401-415.

7. Steinfeld, H.; Gerber, P.; Wassenaar, T.; Castel, V.; Rosales, M.; de Haan, C. Livestock's Long Shadow: Environmental Issues and Options; LEAD/FAO: Rome, Italy, 2006.

8. Mekonnen, M.M.; Hoekstra, A.Y. The Green, Blue and Grey Water Footprint of Farm Animals and Animal Products; Value of Water Research Report Series No. 48; UNESCO-IHE: Delft, The Netherlands, 2010.

9. The United Nations Educational, Scientific and Cultural Organization (UNESCO-WWAP). The United Nations World Water Development Report 3: Water in a Changing World; The United Nations Educational, Scientific and Cultural Organization: Paris, France, 2009.

10. Zonderland-Thomassen, M.A.; Lieffering, M.; Ledgard, S.F. Water footprint of beef cattle and sheep produced in New Zealand: Water scarcity and eutrophication impacts. J. Clean. Prod. 2014, 73, 253-262.

11. Van Huis, A.; van Itterbeeck, J.; Klunder, H.; Mertens, E.; Halloran, A.; Muir, G.; Vantomme, P. Edible Insects-Future Prospects for Food and Feed Security; FAO Forestry Paper 171; Food and Agriculture Organization of the United Nations: Rome, Italy, 2013. Available online: http://www.fao.org/docrep/018/i3253e/i3253e00.htm (accessed on 31 July 2015).

12. Mitsuhashi, J. The future use of insects as human food. In Forest Insects as Food: Humans Bite Back; Food and Agriculture Organization of the United Nations Regional Office for Asia and the Pacific: Bangkok, Thailand, 2010; pp. 115-122.

13. Hoekstra, A.Y.; Chapagain, A.K. Water footprints of nations: Water use by people as a function of their consumption pattern. Water Resour. Manag. 2007, 21, 35-48.

14. Srivastava, S.K.; Babu, N.; Pandey, H. Traditional insect bioprospecting-As human food and medicine. Indian J. Tradit. Knowl. 2009, 8, 485-494. 
15. Verkerk, M.C.; Tramper, J.; van Trijp, J.C.M.; Martens, D.E. Insect cells for human food. Biotechnol. Adv. 2007, 25, 198-202.

16. Bukkens, S.G.F. The nutritional value of edible insects. Ecol. Food Nutr. 1997, 36, 287-319.

17. Wattanathorn, J.; Muchimapura, S.; Boosel, A.; Kongpa, S.; Kaewrueng, W.; Tong-Un, T.; Wannanon, P.; Thukhammee, W. Silkworm pupae protect against Alzheimer's disease. Am. J. Agric. Biol. Sci. 2012, 7, 330-336.

18. Schiefenhövel, W.; Blum, P. Insects: Forgotten and rediscovered as ford. Entomophagy among the Eipo, highlands of West New Guinea, and in other traditional societies. In Consuming the Inedible; MacClancy, J., Henry, J., Macbeth, H., Eds.; Berghaghn Books: New York, NY, USA, 2009; pp. 163-176.

19. Jongema, Y. List of Edible Insect Species of the World; Laboratory of Entomology, Wageningen University: Wageningen, The Netherlands, 2102. Available online: http://www.wageningenur.nl/ upload_mm/7/e/6/c79e66db-00d5-44c9-99cb-f38943723db6_LIST\%20Edible\%20insects\%201st \%20of\%20April.pdf (accessed on 31 July 2015).

20. Ramos-Elorduy, J. Anthropo-entomophagy: Cultures, evolution and sustainability. Entomol. Res. 2009, 39, 271-288.

21. Makkar, H.P.S.; Tranb, G.; Heuzéb, V.; Ankers, P. State-of-the-art on use of insects as animal feed. Anim. Feed Sci. Technol. 2014, 197, 1-33.

22. Oonincx, D.G.; de Boer, I.J. Environmental impact of the production of mealworms as a protein source for humans-A life cycle assessment. PLOS ONE 2012, 7, doi:10.1371/journal.pone.0051145.

23. Oonincx, D.G.; van Itterbeeck, J.; Heetkamp, M.J.; van den Brand, H.; van Loon, J.J.; van Huis, A. An exploration on greenhouse gas and ammonia production by insect species suitable for animal or human consumption. PLOS ONE 2010, 5, doi:10.1371/journal.pone.0014445.

24. Hoekstra, A.Y.; Chapagain, A.K.; Aldaya, M.M.; Mekonnen, M.M. The Water Footprint Assessment Manual: Setting the Global Standard; Earthscan: London, UK, 2011.

25. Chapagain, A.K.; Hoekstra, A.Y. Water Footprints of Nations; Value of Water Research Report Series No. 16; UNESCO-IHE: Delft, The Netherlands, 2004. Available online: http://www.water footprint.org/Reports/Report16Vol1.pdf (accessed on 31 July 2015).

26. Chapagain, A.K.; Hoekstra, A.Y. Virtual Water Flows between Nations in Relation to Trade in Livestock and Livestock Products; Value of Water Research Report Series No. 13; UNESCO-IHE: Delft, The Netherlands, 2003. Available online: http://www.waterfootprint.org/Reports/ Report13.pdf (accessed on 31 July 2015).

27. Mekonnen, M.M.; Hoekstra, A.Y. The Green, Blue and Grey Water Footprint of Crops and Derived Crop Products; Value of Water Research Report Series No. 47; UNESCO-IHE: Delft, The Netherlands, 2010. Available online: http://www.waterfootprint.org/Reports/Report47-Water FootprintCrops-Vol2.pdf (accessed on 31 July 2015).

28. Mekonnen, M.M.; Hoekstra, A.Y. The green, blue and grey water footprint of crops and derived crop products. Hydrol. Earth Syst. Sci. 2011, 15, 1577-1600.

29. Barker, D.; Fitzpatrick, M.P.; Dierenfeld, E.S. Nutrient composition of selected whole invertebrates. Zoo Biol. 1998, 17, 123-134. 
30. Bernard, J.B.; Allen, M.E. Feeding Captive Insectivorous Animals: Nutritional Aspects of Insects as Food. Nutrition Advisory Group Handbook. 1997. Available online: http://www.prairieexotics. ca/info/Nutritional_Aspects_of_Insects_as_Food.pdf(accessed on 31 July 2015).

31. Finke, M.D. Complete nutrient composition of commercially raised invertebrates used as food for insectivores. Zoo Biol. 2002, 21, 269-285.

32. Ng, W.K.; Liew, F.L.; Ang, L.P.; Wong, K.W. Potential of mealworm (Tenebrio molitor) as an alternative protein source in practical diets for African catfish, Clarias gariepinus. Aquac. Res. 2001, 32, 273-280.

33. De Vries, M.; de Boer, I.J.M. Comparing environmental impacts for livestock products: A review of life cycle assessments. Livest. Sci. 2010, 128, 1-11.

34. Smil, V. Worldwide transformation of diets, burdens of meat production and opportunities for novel food proteins. Enzym. Microb. Technol. 2002, 30, 305-311.

35. Gerbens-Leenes, P.W.; Mekonnen, M.M.; Hoekstra, A.Y. The water footprint of poultry, pork and beef: A comparative study in different countries and production systems. Water Resour. Ind. 2013, $1,25-36$.

36. Aguilar-Miranda, E.D.; López, M.G.; Escamilla-Santana, C.; de la Rosa, A.P. Characteristics of maize flour tortilla supplemented with ground Tenebrio Molitor Larvae. J. Agric. Food Chem. 2002, 50, 192-195.

37. Ghaly, A.E.; Alkoaik, F.N. The yellow mealworm as a novel source of protein. Am. J. Agric. Biol. Sci. 2009, 4, 319-331.

38. Siemianowska, E.; Kosewska, A.; Aljewicz, M.; Skibniewska, K.A.; Polak-Juszczak, L.; Jarocki, A.; Jedras, M. Larvae of mealworm (Tenebrio molitor L.) as European novel food. Agric. Sci. 2013, 4, 287-291.

39. Gerber, P.; Wassennar, T.; Rosales, M.; Castel, V.; Steinfield, H. Environmental Impacts of a changing livestock production: Overview and discussion for a comparative assessment with other food production sectors. In Comparative Assessment of the Environment Costs of Aquaculture and Other Food Production Sectors: Methods of Meaningful Comparisons, Proceedings of the FAO/WFT Expert Workshop on Comparative Assessment of the Environmental Costs of Aquaculture and Other Food Production Sectors, Vancouver, BC, Canada, 24-28 April 2006; Bartley, D.M., Brugère, C., Soto, D., Gerber, P., Harvey, B., Eds.; Volume 10, pp. 37-54.

40. Seré, C.; Steinfeld, H.; Groenewold, J. World Livestock Production Systems: Current Status, Issues and Trends. 1995. Available online: http://www.fao.org/3/a-w0027e.pdf (accessed on 31 July 2015).

41. Rumpold, B.A.; Schlüter, O.K. Potential and challenges of insects as an innovative source for food and feed production. Innov. Food Sci. Emerg. Technol. 2013, 17, 1-11.

42. Murray, D.R.P. The importance of water in the normal growth of larvae of Tenebrio Molitor. Entomol. Exp. Appl. 1968, 11, 149-168.

43. Roe, R.M.; Clifford, C.W.; Woodring, J.P. The effect of temperature on energy distribution during the last-larval stadium of the female house cricket, Acheta domesticus. J. Insect Physiol. 1985, 31, 371-378. 
44. Van Broekhoven, S.; Oonincx, D.G.; van Huis, A.; van Loon, J.J. Growth performance and feed conversion efficiency of three edible mealworm species (Coleoptera: Tenebrionidae) on diets composed of organic by-products. J. Insect Physiol. 2015, 73, 1-10.

45. Premalatha, M.; Abbasi, T.; Abbasi, T.; Abbasi, S.A. Energy-efficient food production to reduce global warming and ecodegradation: The use of edible insects. Renew. Sustain. Energy Rev. 2011, 15, 4357-4360.

(C) 2015 by the authors; licensee MDPI, Basel, Switzerland. This article is an open access article distributed under the terms and conditions of the Creative Commons Attribution license (http://creativecommons.org/licenses/by/4.0/). 